\title{
EFFECT OF ADDING DRY YEAST OR ASPERGILLUS AWAMORI AS NATURAL ANTIOXIDANTS TO DIETS CONTAINING OXIDIZED PALM OIL ON THE PERFORMANCE OF GIMMIZAH LAYING HENS
}

\author{
A. M. H. Abou-Ashour, G. A. Zanaty and Esraa Y. F. Ata Alah \\ Department of Poultry and Fish production, Faculty of Agriculture, Menoufia University, \\ Shibin EI - Kom, Egypt.
}

Received: Oct. 14, 2020

Accepted: Nov. 15, 2020

\begin{abstract}
In this study, one hundred and eighty (180), 28 weeks old Gimmizah laying hens were used to study the effects of adding a probiotic (dry yeast or Aspergillus awamori) as natural antioxidant agents to diets containing oxidized palm oil on the productive performance, egg quality traits, some blood components, economic efficiency and relative economic efficiency of Gimmizah laying hens. Hens were distributed at random into 6 similar treatment groups. Each treatment group was divided into 3 replicates of 10 layers each in a completely randomized design. Layers were housed in individual cages. The first group was fed a basal diet contains $16.41 \%$ crude protein, $2748 \mathrm{ME} \mathrm{kcal} / \mathrm{kg}$ diet (positive control). The second group was fed basal diet contained $2 \%$ oxidized dietary palm oil supplementation (negative control). Other groups three and four were fed negative control supplemented with $0.5 \%$ and $1 \%$ dry yeast (Saccharomyces cervices), respectively. While, five and six groups were fed the negative control with $0.5 \%$ and $1 \%$ Aspergillus awamori, respectively. Results obtained; the addition of $1 \%$ Aspergillus awamori to the negative control group containing $2 \%$ of the oxidized palm oil improved: Hen-day egg production percentage, egg weight, egg number and egg mass. Feed conversion ratio was significantly $(P \leq 0.05)$ improved by adding $0.5 \%$ or $1 \%$ of both dry yeast and Aspergillus awamori to the negative control diet. A significant increase in the amount of feed intake was observed compared to the negative or positive control. The $6^{\text {th }}$ birds which feeding of the negative control diet + $1 \%$ Aspergillus awamori significantly recorded the highest improvement in egg shell quality (weight, percentage and thickness) also the highest value of egg shape index at the age of $\mathbf{4 0}$ weeks. Some of the qualities of albumen, yolk and Haugh units were also improved. The addition of $1 \%$ Aspergillus awamori to the negative control diets (the basal diet $+2 \%$ oxidized palm oil) resulted in a significant improvement in some traits of blood plasma (total protein, albumin, globulin and AST enzyme in comparison with the positive and the negative control diets. A significant decrease was observed in the level of total cholesterol and triglyceride concentration as well as LDL, while HDL was significantly increased $(P \leq 0.05)$ in the blood plasma by increasing the levels of probiotics (dry yeast or Aspergillus awamori) added to negative control. The best economic efficiency and relative economic efficiency for the sixth treatments were observed at the level of $1 \%$ Aspergillus awamori compared to other treatments.
\end{abstract}

Conclusion: The obtained results in the present study encouraging and indicated that adding $1 \%$ of probiotics (dry yeast or Aspergillus awamori) as antioxidant agents to the basal diet containing $2 \%$ of oxidized palm oil led to a significant improvement in productive performance, egg quality traits, some blood traits, economic efficiency and relative economic efficiency of Gimmizah laying hens under experimental conditions.

Key words: Oxidized palm oil, Saccharomyces cervices, Aspergillus awamori, egg production, egg quality traits, Plasma blood parameters, blood lipid profile and laying hens. 


\section{INTRODUCTION}

Poultry production is a business which like any other business seeks to generate profit, one of the objectives of any poultry producer is to keep the balance between low coast diets with the least coast and obtain the maximum productivity (Ahiwe, et al., 2018). Oils are added into poultry diets to supply energy and essential fatty acids, as a vitamin vehicle, and to alleviated acute heat stress (Mujahid et al., 2009). Vegetable oils contain large amounts of polyunsaturated fatty acid, such as palm oil, which is susceptible to peroxidation (Liu et al., 2014).

Heated oils contain various amounts of peroxidation products (Zhang et al., 2012), such as 4-hydroxynonenal, hydroperoxide, malondialdehyde, and 2,4-heptadienal (Choe and Min, 2007), which influence oil odor, palatability, and quality (Smyk, 2015).

Several studies reported that the consumption of oxidized fats affects metabolism in several ways (Skufca, et al., 2003), in multiple animal species (Ehr et al., 2015), oxidized oils decrease feed intake, depress growth, and even cause disease. Feeding oxidized oils impaired the growth performance and induced oxidative stress in broiler and laying hens (Wang et al., 2015). Feeding oxidized soybean oil impaired growth broilers and antioxidant activities (Tan et al., 2018). In poultry, oxidative stress may occur due to several factors such as: a) feed (high concentration of polyunsaturated fatty acids [PUFA], contamination with fungal toxins, prolonged storage and antioxidant deficiency) (Chung, et al., 2005), b) environmental (heat, high stocking density, transportation, and vaccination) (Panda, et al., 2008), c) Pathological conditions (ascites, fatty liver haemmorrhagic disease syndrome arthritis and coccidiosis) (Iqbal, et al., 2002).

Therefore, in recent years, different studies have been attempted to find nutrition-based on health strategies and natural alternatives instead of antibiotics and suggested that probiotics, prebiotics, organic acids or natural feed additives can replace the growthpromoting antibiotics and antioxidant properties (Abudabos et al., 2017).

Among these feed additives, probiotics have drawn great attention. FAO/WHO (2001) describes probiotics as "live micro-organisms which" when administered in adequate amounts, confer a health benefit on the host. Probiotics are live microbial culture, such as bacteria, yeast and fungi, which influence the health and nutrition of the host by improving its intestinal microbial balance (Zarei et al., 2018).

Aspergillus awamori, a variant of Aspergillus niger, is one of the fungi had long been used for processing foods because it safe, produce enzymes such as amylase, protease, pectinase and lipase, and thus enhances the digestion of carbohydrates, proteins and lipids. Also, feasible yeast feedstuffs are normally included into poultry diets as probiotic. Also, Saccharomyces cerevisiae has biologically valuable proteins, vitamin B-complex, mannan oligosaccharide, important trace minerals and several unidentified growths promoting factors. Yeast contains digestible proteins especially in the form of free amino acids and peptides, functional nucleic acids and natural immune enhancer such as $\beta$-glucan and mannan oligosaccharides.

Inclusion of probiotic in the diet has been found to improve egg production and feed conversion ratio (Chung et al., 2015). Furthermore, giving probiotics to laying hens has been found to improve 
eggshell quality and feed efficiency (Sobczak and Kozłowski, 2015).

Therefore, this study was conducted to investigate the effects of adding probiotic (dry yeast or Aspergillus awamori) as antioxidant agents to diets containing oxidized palm oil on the productive performance, egg quality traits, some blood components, economic efficiency and relative economic efficiency of Gimmizah laying hens.

\section{MATERIALS AND METHODS}

The experiment was performed at a private farm in Tanta, Gharbia Governorate, Egypt, during the period from December 2017 to February 2018. This experiment was conducted to investigate the effects of adding probiotics (dry yeast or Aspergillus awamori) as antioxidant agents to diets containing oxidized palm oil on the productive performance, egg quality traits, some blood components, economic efficiency and relative economic efficiency of Gimmizah laying hens.

\section{1- Birds:}

One hundred and eighty (180), 28 weeks old Gimmizah laying hens were used in this experiment. Hens were distributed at random into 6 similar treatment groups and divided into 3 replicates of 10 layers each in a completely randomized design. Layers were housed in individual cages with a size of $44 \mathrm{H} \times 30 \mathrm{~W} \times 45 \mathrm{~cm} \mathrm{~L}$ and were equipped with nipple drinkers and trough feeders.

\section{2- Feeds and feeding:}

The composition of the basal diet $\left(\mathrm{T}_{1}\right.$; positive control) is given in Table 1 . The first group was fed a basal diet contains $16.41 \%$ crude protein, $2748 \mathrm{ME} \mathrm{kcal} / \mathrm{kg}$ diet (positive control). The second group was fed basal diet contained $2 \%$ oxidized dietary palm oil supplementation (negative control). Other groups three and four were fed negative control supplemented with $0.5 \%$ and $1 \%$ dry yeast (Saccharomyces cervices), respectively. While, five and six groups were fed the negative control with $0.5 \%$ and $1 \%$ Aspergillus awamori, respectively. Oxidized palm oil, $(200 \mathrm{mEq}$ of peroxide number/ $\mathrm{kg}$ oil) was prepared at laboratories of Agriculture research center, Ministry of Agriculture, by aeration the refind palm oil at $145 \mathrm{C}^{\circ}$ for 24 hours (Dror et al., 1976).

The peroxide value was calculated as follow:

Peroxide number $(\mathrm{mEq} / \mathbf{k g}$ oil $)=$ Volume of thiosulphate $\times$ Standard $(0.01) \times 1000 \div$ Weight of sample.

While, the probiotic microbial strains used in this study were obtained from Microbiological Research Center (Cairo, Egypt). The probiotic consists of Aspergillus awamori spores was about $25 \times 10^{4} \mathrm{~g}$. Also, dried active yeast S.cerevisia factory strain, used in this study, was provided by a commercial company (The Egyptian Company for Starch, Yeast and Detergents, Co., Ltd.; Alexandria, Egypt). The number of saccharomyces cervices F- 7 visiae factory strain 27 spores was CFU $2 \times 10^{10}$ g. Probiotic and dry yeast were in dried powder form and were thoroughly mixed in the negative diet.

Mixing of oxidized palm oil supplemented diets was done weekly and nutrient requirements were calculated recommend by the National Research Council (NRC, 1994). Feed and water were provided ad libitum during the experimental period. Artificial light was used beside the normal day light to provide 16 hour photo period from 06 am to $10 \mathrm{pm}$. The laying hens were kept in optimal and standard bio - climatic and welfare conditions and average 
Table 1. Composition and chemical analysis of the experimental laying diets.

\begin{tabular}{lcc}
\hline Ingerdiets & Positive control (\%) & Negative controle (\%) \\
\hline Ground yellow corn (8.5\%). & 64.98 & 58.30 \\
Soybean meal (44\%). & 24.68 & 24.19 \\
Wheat bran (15\%). & 0.21 & 5.38 \\
Oxidized palm oil. & - & 2.00 \\
Limestone ground. & 7.49 & 7.49 \\
Di-calcium phosphate. & 1.95 & 1.95 \\
Vitamin and mineralmi mixture ${ }^{1 .}$ & 0.30 & 0.30 \\
DI-Methionine ${ }^{2}$. & 0.06 & 0.06 \\
Sodium cholorid (salt). & 0.33 & 0.33 \\
\hline Total & 100 & 100 \\
\hline Caculated values ${ }^{3}:$ & & \\
Crude protien, CP (\%). & 16.41 & 16.41 \\
ME, kcal/ kg diet. & 2748 & 2735 \\
C/ p ratio. & 167 & 167 \\
Lysine, \%. & 0.83 & 0.83 \\
Methionine, \%. & 0.33 & 0.33 \\
Calcium, \%. & 3.38 & 3.38 \\
Av. Phosphorus, \%. & 0.52 & 0.52 \\
\hline Determined values: & & 90.11 \\
Dry matter, \%. & 90.27 & 16.40 \\
Crude proteine, \%. & 16.44 & 3.01 \\
Ether extract, \%. & 2.29 & 3.46 \\
Crude fiber, \%. & 3.12 & 3.40 \\
Calcium, \%. & 3.44 & 0.51 \\
Av. phosphorus, \%. & 0.50 & \\
\hline Vitmin and Min & & \\
\hline
\end{tabular}

${ }^{1}$ Vitamin and Mineral mixture at $0.30 \%$ of the diet supplies the following per kilogram of the diet: Vitamin $A 12,000 \mathrm{IU}$, vitamin $D_{3} 3,000 \mathrm{IU}$, vitamin E $40 \mathrm{mg}$, vitamin $K_{3} 3 \mathrm{mg}$, vitamin $B_{1} 2 \mathrm{mg}$, vitamin $B_{2} 6 \mathrm{mg}$, vitamin $B_{6} 5 \mathrm{mg}$, vitamin $B_{12} 0.02 \mathrm{mg}$, niacin $45 \mathrm{mg}$, biotin $0.075 \mathrm{mg}$, folic acid 2 $\mathrm{mg}$, pantothenic acid $12 \mathrm{mg}$, manganese $100 \mathrm{mg}$, zinc $600 \mathrm{mg}$, iron $30 \mathrm{mg}$, copper $10 \mathrm{mg}$, iodine 1 $\mathrm{mg}$, selenium $0.2 \mathrm{mg}$, cobalt $0.1 \mathrm{mg}$.

${ }^{2} \mathrm{DL}$ - Methionine: $98 \%$ feed grade (98\% Methionine).

${ }^{3}$ Calculate according to NRC (1994).

\section{Parameters were measured and obtained:}

3.1. Egg number, egg weight and egg mass.

Daily egg production for each dietary treatment group and individual egg 
weight were recorded. Means of egg weight as well as egg mass of each treatment group were determined. Egg production performance was also considered during experimental period.

\subsection{Feed intake and feed conversion ratio for egg production.}

Total Feed intake/ dietary treatment group/ day was recorded and expressed as feed (g)/ bird/day. Feedconversion ratio was determined as feed (g)/ egg mass (g).

\subsection{Egg quality traits.}

Nine eggs (9) were randomly collected from each dietary treatment groups were at $\mathbf{4 0}$ weeks of age for the determination of the following egg quality traits:

\subsubsection{External egg quality measures.}

a. Egg shape index (ESI) (\%):

Egg shape index were calculated from length and width, measure by digital a tripod micro meter according to Romanoff and Romanoff (1949) as follows: Egg shape index= width $(\mathrm{mm}) /$ length $(\mathrm{mm}) \times 100$.

b. Eggshell quality.

- Eggshell thickness (ST), without its membranes, was determined according to Brant and Shrader (1952) by using micrometer (to the nearest $0.01 \mathrm{~mm}$ ) at the broad, narrow and the middle ends. Average of shell thickness for all three regions were calculated.

- Eggshell weight and eggshell percent were calculated as follows:

Eggshell percent $=$ eggshell weight,g/ egg weight,g $\times 100$.

\subsubsection{Internal egg quality measures.}

Eggs were individually weighted, then broken on a flat glass plat and thick albumen and yolk heights were measured to the nearest $(\mathrm{mm})$ with a tripod micro meter, yolk diameter was also recorded to the nearest $(\mathrm{mm})$ with a digital caliper according to Funk (1948) and Romanoff and Romanoff (1949), these data used to estimate the yolk index value:

a. Egg yolk index (\%).

It was estimated as a ratio between yolk height $(\mathrm{mm})$ and its widths $(\mathrm{mm}$.) as follows:

Yolk index $(\mathrm{YI}, \%)=$ yolk height $(\mathrm{mm}) /$ yolk width $(\mathrm{mm}) \times 100$.

b. Egg yolk visual color.

The egg yolk visual color was determined by matching the yolk with one of the 15 bands. The Roche yolk color fan-an instrument for measuring yolk color by (Rauch, 1961).

c. Egg albumen index (\%).

It was calculated from albumen (A) height $(\mathrm{mm})$ and width $(\mathrm{mm})$ that were measured with a tripod micrometer according to Romanoff and Romanoff (1949) as follows:

Albumen index (Al, \%) = albumen height $(\mathrm{mm}) /$ albumen width $(\mathrm{mm}) \times$ 100.

\section{d. Haugh unit.}

It was applied from a special chart using egg weight and albumen height which was measured using a tripod micro - meter according to Haugh (1937), Eisen et al. (1962) and Kotaiah and Mohapatra (1974) as follows:

Haugh unit $=100 \log \left(\mathrm{H}+7.57-1.7 \mathrm{w}^{0.37}\right)$

Where: $\mathbf{H}=$ albumen height $(\mathrm{mm})$

$$
\mathbf{w}=\text { egg weight }(\mathrm{g}) \text {. }
$$

\subsection{Blood parameters and blood lipid profile:}

At the end of the experiment (40 weeks of age), blood samples were taken from the wing vein from 3 laying hens / treatment. Blood samples were collected in sterile heparinized centrifuge tubes. Plasma samples were separated by centrifugation at $3000 \mathrm{rpm}$. for $15 \mathrm{~min}$ and then stored frozen at $-20 \mathrm{C}^{\circ}$ for the 
determination of total protein, albumin, and glucose and liver enzymes as (ALT and AST) and (lipid profile (triglycerides, total protein, HDL and LDL).

a. Total protein concentration (TP): It was quantitatively measured as ( $\mathrm{g} / \mathrm{dl}$ ) based on colorimetric determination as described by Henry et al. (1974).

b. Albumin concentration (Alb): It was determined as $(\mathrm{g} / \mathrm{dl})$ by using special kits delivered from sentinel $\mathrm{CH}$. Milano, Italy according to the method of Doumas et al. (1977).

c. Globulin concentration: It was calculated by subtracting the values of the albumin from total protein values.

d. Glucose concentration (Glu.): It was measured as $(\mathrm{mg} / \mathrm{dl})$ by the method of Trinder (1969) using commercial kits delivered from Linear chemicals Cromatest, Barcelona (Spain) by means of spectrophotometer.

e. Liver function: The transaminase enzymes activities of serum alanine aminotransferase (ALT) and plasma asparate amino transferase (AST), were determined by calorimetric method of Reitman and Frankel (1957).

f. Blood lipid profile: Total triglyceride, total cholesterol, high-density lipoprotein (HDL) and low-density lipoprotein (LDL) were determined in plasma blood Gimmizah hens.

f.1. Total triglyceride concentration (TG):

It was determined as $(\mathrm{mg} / \mathrm{dl})$ depending on the method of Allain et al. (1974).

f.2. Total cholesterol concentration (Cho): It was determined as $(\mathrm{mg} / \mathrm{dl})$ on individual base using the specific kits according to the recommendation of Bogin and Keller (1987). High-density lipoprotein (HDL) and low-density lipoprotein (LDL) were detwrmined, using an ultraviolet spectophotomater UV 4802 (Unico, Dayton, US) and commercially available kits
(Biosystem S.A, Costa Brava,30, Barcelone, Spain).

\subsection{Chemical analysis of feed samples:}

The composition of the experimental basal diets were based in tabulated values for feed stuffs NRC (1994). Feed samples of the experimental basal diets were taken for proximate analysis. Moisture, crude protein, ether extracet, crude fiber and ash were determind according to the official methods of AOAC (2005).

\subsection{Economic efficiency.}

Economic efficiency for egg production was calculated from the input - output analysis (Heady and Jensen, 1954), according to the price of the experimental diets and egg production. Values of economic efficiency were calculated as the net revenue per unit of total costs (Soliman and Abdo, 2005).

\subsection{Statistical analyses.}

The experiment was conducted using a completely randomized design using SPSS (2011) program and the difference among treatment means were determined using Duncan's multiple range test (Duncan, 1955). Percentages were transformed to the corresponding arcsine values before performing statically analysis.

Statically model:

$$
Y i j=\mu+\alpha i+E i j \text {. }
$$

Where:

Yij = observed traits,

$\mu=$ overall mean,

$\alpha i=$ effect of treatment $(i=1,2,3, \ldots \ldots 6)$.

Eij $=$ experimental random error.

\section{RESULTS AND DISCUSSION}

Effect of dietary oxidized palm oil and probiotic on the productive performance of laying hens. 
1- Egg production traits.

1.1. Egg number.

Data in Table (2) indicated that egg number/ hen was significantly increased. Egg number values were 50.20, 50.94, 51.00 and 52.05 eggs/ hen for 0.5 and $1 \%$ Saccharomyces cerevisia and 0.5 and $1 \%$ Aspergillus awamori, respectively. Average of $41.73 \mathrm{eggs} /$ hen was obtained for the negative control diet (basal diet with $2 \%$ oxidized palm oil) compared to 47.70 eggs/ hen for the positive control (basal diet). The findings reported by different authors concerning that egg number indicate wide variability with respect to the effect of dietary dry yeast and probiotic Maziar et al. (2007), similarly to the results obtained in this experiment, Saleh et al. (2017) and Kaiaty et al. (2019) reported a significant improvement in performance and egg number in hens fed diet supplemented with a product containing Aspergillus awamori and dry yeast. The presented data are dis agree with those of Elnagar (2013) who reported that yeast supplementation at levels of 3 or $6 \mathrm{~g} / \mathrm{kg}$ diet significantly decreased egg number.

\subsection{Egg weight.}

Experimental results indicated that egg weight was increases with dry yeast and probiotic supplementation (Table 2). Means of egg weight were $52.45,52.86$, $53.98,54.01$ and $54.33 \mathrm{~g}$ for the positive control, 0.5 and $1 \%$ Saccharomyces cerevisia and 0.5 and $1 \%$ Aspergillus awamori supplemented diets, respectively. The highest value of average egg weight noted when laying hens fed $1 \%$ Aspergillus awamori, ( $T_{6}$, $54.33 \mathrm{~g}$ ) compared to $52.00 \mathrm{~g}$ in the negative control diet which recorded the lowest value. These results are in agreement with those of Chumpawadee et al. (2009) who found a significant difference were observed in egg weigh by addition of Cassava yeast as probiotic source. Similar significant results in egg weight were also obtained in hens fed diets supplemented with a mixture of probiotic content Lactobacillus cultures (Kalavathy et al., 2009 and Saleh et al., 2017).

In contrast, our results are opposite to the results of Gül et al. (2013); Sacakli et al. (2013); Yalçin et al. (2014) and Tapingkae et al. (2018) who stated that, egg weight was not affected by adding yeast into diet.

\subsection{Egg mass.}

Diets supplemented with oxidized palm oil and probiotic, generally, resulted in a higher egg mass (Table 2) during the different experimental periods. Egg mass was significantly increased $(P \leq$ 0.05 ) with increasing dry yeast and probiotic levels ( 0.5 and $1 \%$ ) being 31.59 , $32.74,32.79$ and $33.67 \mathrm{~g} /$ hen for $T_{3}, T_{4}, T_{5}$ and $T_{6}$, respectively compared to those fed positive and negative control diets (29.78 and $25.83 \mathrm{~g} /$ hen, respectively). Results reported herein are in harmony with these obtained by others researchers reported that egg mass was increased by the dietary supplementation of yeast, yeast products and Aspergillus awamori (Yalcin et al., 2010 and Saleh et al., 2017). The high inclusion of yeast level has an adverse effect on nutrient digestibility (Romashko, 1999).

\subsection{Egg production, \%:}

Experimental results on the effect of dietary oxidized palm oil and probiotic (Saccharomyces cerevisia and Aspergillus awamori) supplementation on egg production percentage at $\mathbf{4 0} \mathbf{w k}$ of age are shown in Table (2). It observed that percentage of egg production was significantly increased $(P \leq 0.05)$. Average of $49.68 \%$ was obtained for the negative control diet (basal diet with $2 \%$ oxidized palm oil) in comparison with $57.03 \%$ for the positive control (basal 


\section{A. M. H. Abou-Ashour, et al.,}

diet). In general, greater improvement $61.91 \%$ for egg production was obtained at level of $1 \%$ Aspergillus awamori, $\mathrm{T}_{6}$ compared to other treatments $(59.23$, 60.43 and $60.65 \%$ ) for $T_{3}, T_{4}$ and $T_{5}$, respectively.

The differences between the results of the

\begin{tabular}{|c|c|c|c|c|c|c|c|c|c|c|}
\hline \multirow{3}{*}{$\begin{array}{l}\text { presen } \\
t \text { study } \\
\text { and } \\
\text { those } \\
\text { of } \\
\text { previo } \\
\text { us } \\
\text { studie } \\
\text { s may } \\
\text { be due } \\
\text { to the } \\
\text { specie } \\
\text { s and } \\
\text { age of } \\
\text { the } \\
\text { birds, } \\
\text { dietary }\end{array}$} & & \multicolumn{2}{|c|}{ 昜 } & \multirow{2}{*}{ 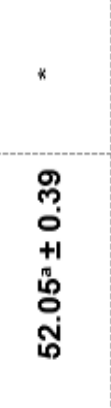 } & \multirow{2}{*}{ 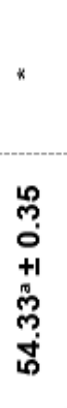 } & \multirow{2}{*}{ 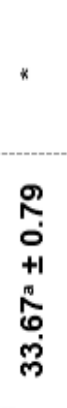 } & \multirow{2}{*}{ 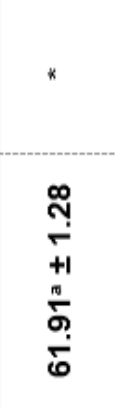 } & \multirow{2}{*}{ 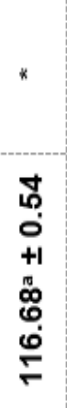 } & \multirow[b]{2}{*}{$\begin{array}{l}5 \\
0 \\
0 \\
+1 \\
0 \\
0 \\
\dot{0} \\
\text { r. }\end{array}$} & \multirow[b]{2}{*}{ 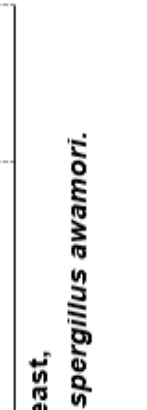 } \\
\hline & & & $\vdash ீ$ & & & & & & & \\
\hline & & & トீ & $\begin{array}{l}\bar{y} \\
0 \\
+1 \\
+1 \\
8 \\
\vdots \\
\vdots \\
0\end{array}$ & $\begin{array}{l}\infty \\
\stackrel{0}{0} \\
+1 \\
+1 \\
0 \\
0 \\
\dot{1}\end{array}$ & 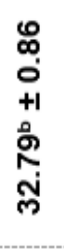 & \begin{tabular}{l}
\multirow{0}{0}{} \\
$\dot{+}$ \\
+1 \\
+1 \\
$\stackrel{0}{0}$ \\
0 \\
0
\end{tabular} & 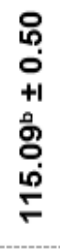 & 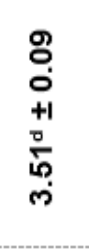 & 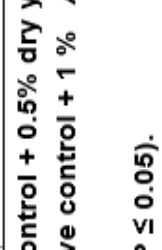 \\
\hline $\begin{array}{l}\text { birds, } \\
\text { dietary }\end{array}$ & & 离 & $\stackrel{\bullet}{ }$ & 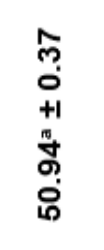 & 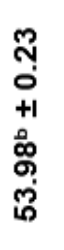 & 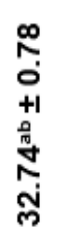 & 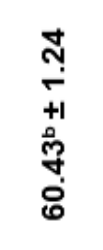 & $\begin{array}{l}0 \\
0 \\
0 \\
+1 \\
+1 \\
0 \\
0 \\
\frac{0}{0} \\
\stackrel{0}{\circ}\end{array}$ & $\begin{array}{l}\infty \\
0 \\
0 \\
+1 \\
\text { तें } \\
\text { ஸे } \\
\text { p. }\end{array}$ & 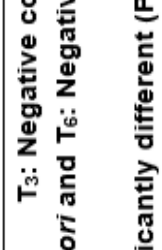 \\
\hline & 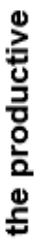 & $\begin{array}{l}\frac{1}{2} \\
\frac{5}{5} \\
\frac{0}{0}\end{array}$ & $\vdash^{m}$ & 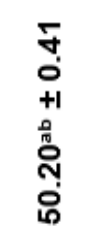 & $\begin{array}{l}\stackrel{0}{0} \\
\stackrel{0}{0} \\
+1 \\
\stackrel{0}{0} \\
\stackrel{0}{0}\end{array}$ & 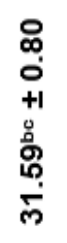 & 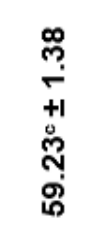 & 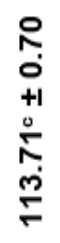 & \begin{tabular}{l}
\multicolumn{5}{c}{} \\
\\
+1 \\
+1 \\
0 \\
0 \\
$\dot{m}$
\end{tabular} & 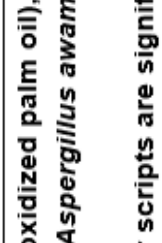 \\
\hline & o & & $\vdash^{N}$ & 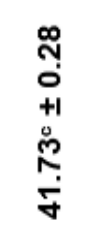 & 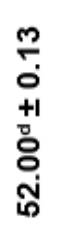 & $\begin{array}{l}\text { पू } \\
0 \\
+1 \\
+1 \\
0 \\
0 \\
\omega \\
\omega\end{array}$ & 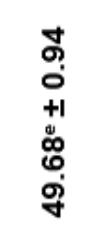 & 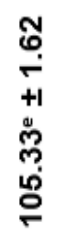 & $\begin{array}{l}8 \\
0 \\
0 \\
+1 \\
+1 \\
\infty \\
0 \\
\dot{+}\end{array}$ & 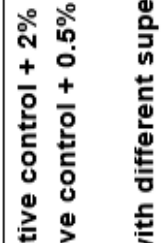 \\
\hline & $\frac{8}{d}$ & & $F$ & \begin{tabular}{l} 
o \\
0 \\
+1 \\
+1 \\
0 \\
\multirow{2}{*}{} \\
f
\end{tabular} & 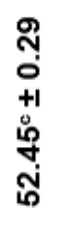 & $\begin{array}{l}\stackrel{2}{N} \\
0 \\
+1 \\
0 \\
0 \\
N \\
\text { N }\end{array}$ & 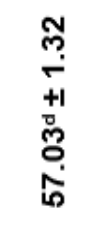 & $\begin{array}{l}\hat{\infty} \\
0 \\
+1 \\
+1 \\
\stackrel{0}{0} \\
\dot{0} \\
\stackrel{+}{=}\end{array}$ & $\begin{array}{l}5 \\
0 \\
0 \\
+1 \\
0 \\
0 \\
0 \\
0\end{array}$ & 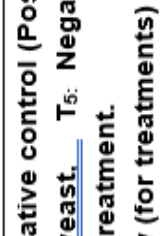 \\
\hline & + & & & 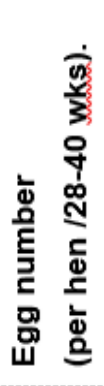 & 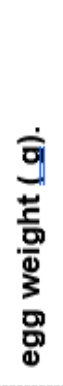 & 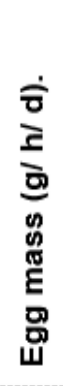 & 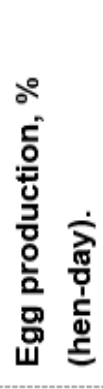 & 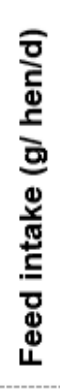 & 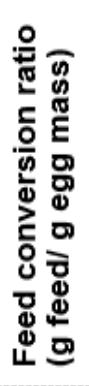 & 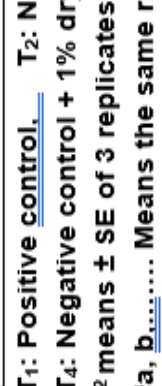 \\
\hline
\end{tabular}

nutrient composition, type, dosage and composition of yeast and probiotic in the diets and environmental conditions. Saccharomyces spp supplementation 
increased egg production and its total weight, this may be due to the fact that the present of probiotic in the digestive tract of poultry may improve digestibility of nutrients, particularly of protein and minerals (Bidura et al., 2012). The improvement in egg production due to low level of yeast inclusion is in agreement with the result of Yörük et al. (2004) and Shareef and Al-Dabbagh (2009) who observed higher percentage of egg production for hens fed yeast and probiotic supplemented diets than the control hens. Maziar et al. (2007) indicated that dietary supplementation of probiotics, yeast, vitamin E and vitamin C during heat stress caused higher egg production than control group. Similar results have also been obtained by some researcher Chumpawadee et al. (2009) reported considerable improvement in egg production in poultry fed dry yeast. Also, the improvement in egg production in layers might be explained that the dry yeast reduces the pathogenic bacteria load in the intestine and then the nutrients in the diets are efficiently diverted toward production in poultry fed yeast, which might improve egg production in layers (Spring et al., 2000). Raka et al. (2014) reported that the highest hen day production was in layers fed diet supplemented with Liquid Probiotics Mixed Culture (LPMC) containing two types of microorganisms, Lactobacillus and Bacillus species. Bidura and Partama (2016) noticed that layers having probiotic supplementation $(0.20,0.40$, and $0.60 \mathrm{~g}$ of Saccharomyces spp. SB-6/ kg of diet) had a significant increase $(P \leq 0.05)$ in egg production (hen-day production) compared to control birds, Saleh et al. (2017) reported that feeding Aspergillus awamori (AA) significantly increased egg production. Özsoy et al. (2018) obtained an increase in egg production by feeding laying hen's diet supplemented with $0.2 \%$ yeast/ $\mathrm{kg}$ diet. Instead Daneshyar et al. (2009) reported that the addition of probiotics did not have significant effect on egg production and egg mass. Sacakli et al. (2013) and Tapingkae et al. (2018) recorded that dietary supplementation of yeast did not significantly affect hen day egg production of laying hens.

\section{2- Feed intake and feed conversion ratio.}

2.1. Feed intake.

Results in Table (2), showed that feed intake, $\mathrm{Fl},(\mathrm{g} / \mathrm{hen} / \mathrm{day}$ ) was significantly increased by adding dry yeast or Aspergillus awamori compared to the positive and negative control group. Highest value of feed intake was $(116.68 \mathrm{~g} / \mathrm{h} / \mathrm{d}) \mathrm{in}$; hens fed $1 \%$ Aspergillus awamori in comparsion with other treatments. The beneficial effect of Saccharomyces cerevisiae is attributed to the fact that it is a naturally rich source of proteins, minerals and B complex. Elnagar, (2013); Zhang and Kim (2014) and Hussein and Selim (2018) reported an increase in feed intake in chicken fed with multi strain probiotics and yeast addition to the diet. On the other hands, Kim et al. (2002) stated that, feed intake values were not statistically different among yeast feeding groups and control. Previous study reported by some research workers for laying hens (e.g. Wibawa et al., 2014 and Bidura and Partama, 2016) and for broilers (Chumpawadee et al., 2009). They studied the effect of yeasts inclusion in the diet and noted that feed intake was not affected by the supplementation. The obtained results are compatible with Bansalyz et al. (2011) and Yalcin et al. (2012) who found that the feed intake of broilers and laying hens fed diet supplemented with Saccharomyces cerevisiae were remarkably decreased than that of the control. studies indicated that dietary yeast supplementation didn't affect feed intake in laying hens (Asli et al., 2007 and 
Sacakli et al., 2013), laying quail (Önol et al., 2003), and in broiler turkeys (Özsoy and Yalcin, 2011). Also, Saleh et al. (2017) reported that feed intake was decreased by the combination of Aspergillus awamori $(0.05 \%$ AA) and lactic acid bacteria $(0.10 \%$ LAB $)$. El-Kaiaty et al. (2019) found that feed intake for yeasttreated hens was significantly $(P \leq 0.05)$ lowered than that of the control group, the lowest feed intake value was recorded for $0.6 \%$ yeast supplemental group.

\subsection{Feed conversion ratio.}

Data on the effects of dietary supplementation on feed conversion ratio are presented in Table (2). Feed conversion ratio (FCR) was significantly $(P \leq 0.05)$ improved due to probiotic (Saccharomyces cerevisia or Aspergillus awamori) supplementation at levels of 0.5 and $1 \%$; being $3.60,3.52,3.51$ and $3.46 \mathrm{~g}$ feed/ $g$ egg mass for $T_{3}, T_{4}, T_{5}$, and $T_{6}$, respectively. In the absence of probiotic, feed conversion ratios were 4.08 and $3.73 \mathrm{~g} \mathrm{feed} / \mathrm{g}$ egg mass for negative control, $\mathrm{T}_{2}$ (basal diet $+2 \%$ oxidized palm oil) and $T_{1}$, positive control treatments, respectively. The improvement in feed conversion ratio due to feeding Aspergillus may be due to that Aspergillus could improve the nutritional value of the soybean meal because the trypsin inhibitor contained in soybean could be degraded by Aspergillus (Hong et al., 2004). Birds do not produce enzymes such as cellulase and xylanase, which are required for the digestion of soluble non - starch polysaccharides (NSP). Because Aspergillus produces these enzymes, it improves digestion, resulting in an increase in the metabolic energy of diets (Mohan et al., 1996). These may be the major reason for the more efficient feed utilization in Aspergillus feeding. The improvement in feed conversion ratio due to feeding Aspergillus was in agreement with the results of previous studies (Saleh et al., 2011 and Saleh et al., 2017). Aspergillus may also affect the activities of these enzymes in liver and adipose tissues and influence fat metabolism (Shen et al., 1991 and Mersmann, 1998).

Results reported herein are in agreement with those obtained by Zhang et al. (2005) who observed an improvement in feed conversion ratio of laying hens fed yeast supplemented diets and Hussein and Selim (2018) showed an improvement in feed conversion ratio of broiler chickens fed dried yeast or probiotic. The improvement in feed conversion ratio may be attributed to the improvement in nutrients absorption and utilization associated with adding yeast which reduces the proliferation of enteric harmful bacteria that responsible of malabsorption. Bradley and Savag (1995) observed an improvement in energy utilization due to feeding dietary yeast. Yalcin et al. (2010) reported that feed efficiency was improved with yeast autolysate supplementation at the level of 2,3 and $4 \mathrm{~g} / \mathrm{kg}(P \leq 0.05)$. Some studies showed that probiotic supplementation on feed led to improvement in feed conversion ratio of broilers and layer hens as reported by Puspani et al. (2014) and Umiarti and Bidura (2014). El-Kaiaty et al. (2019) noticed that feed conversion ratio for yeast-treated hens was insignificantly improved compared to the control group. On the contrary, Sacakli et al. (2013) and Sakine et al. (2014) found that yeast and probiotic supplementation had no effect on feed conversion ratio in laying hens, which might be related to the strain of bacteria, concentration and the form of bacteria used (viability, dryness or their products).

3- Egg quality traits.

3.1. Egg shape index.

Effect of supplementation of probiotic 
and oxidized dietary palm oil to layer diet on egg shape index during different periods of production (40 weeks of age) are shown in Table (3). Probiotic (Saccharomyces cerevisia and Aspergillus awamori) supplementation significantly improved egg shape index being values were $79.82,80.16,80.67$ and $81.26 \%$ for 0.5 and $1 \%$ dry yeast $\left(T_{3}\right.$ and $\mathrm{T}_{4}$ ) and 0.5 and $1 \%$ Aspergillus awamori $\left(T_{5}\right.$ and $\left.T_{6}\right)$ at 40 wks of age, respectively. No significance difference between treatment 5 and 6 were noted during 40 weeks of age. Chickens consuming the positive control (basal diet) had on egg shape values of $76.23 \%$ than those consumed the negative control (basal diet with $2 \%$ oxidized palm oil), had egg shape being $75.01 \%$, respectively.

These results are dis agree with with Sakine et al. (2014) who reported that yeast cell wall; YCW supplementation had no significant effect on the mean values of egg shape index and the percentages of egg parts. Similarly yeast culture and yeast autolysate (Yalcin et al., 2010) supplementation did not significantly affect interior and exterior egg quality characteristics.

\subsection{Eggshell weight.}

Findings on the effect of dietary probiotic supplementation on eggshell weight was presented in Table (3). Dietary probiotic supplementation significantly improved eggshell weight at 40 weeks of age. The best values for eggshell weights were $7.81 \mathrm{~g}$ for treatment 6 (negative control $+1 \%$ Aspergillus awamori) compared to the negative and the positive controls of age (5.86 and $6.11 \mathrm{~g}$ ), respectively. Whereas, values of eggshell weights were 6.54 , 7.28 and $7.62 \mathrm{~g}$ for $T_{3}, T_{4}$ and $T_{5}$, respectively at 40 wks of age. Ayanwale et al. (2006) observed that egg shell weight was higher in laying hens fed diets having $7.5 \mathrm{~g} / \mathrm{kg}$ dried yeast. Similar significant results in eggshell quality were also obtained in hens fed diets with a mixture of probiotic contains Lactobacillus cultures (Kalavathy et al. 2009 and Salah et al., 2017). On the other hand, Özsoy et al. (2018) reported that dietary yeast culture supplementation had no significant effect on eggshell weight.

\subsection{Eggshell thickness.}

Supplementation of probiotic as dry yeast and Aspergillus significantly improved $(P \leq 0.05)$ eggshell thickness at 40 weeks of age, high average value of eggshell thickness was $0.423 \mathrm{~mm}$ in the addition of $1 \%$ Aspergillus awamori with negative control diet $\left(\mathrm{T}_{6}\right)$ and levels of $1 \%$ dry yeast and $0.5 \%$ Aspergillus supplementation had no significant effect between $T_{4}(0.389 \mathrm{~mm})$ and $T_{5},(0.398 \mathrm{~mm})$ (Table 3), respectively.

The improvement in eggshell weight and egg shell thickness may be attributed to the enhancement of calcium absorption and retention associated with adding yeast into the diet (Tangendjaja and Yoon, 2002). Park et al. (2001) reported that, hens fed diets with yeast produced less soft shell and broken egg than control group. This results of (Chumpawadee et al. (2009); Elnagar, (2013) and El-Kaiaty et al. (2019) who recorded that eggshell thickness values were significantly higher by saccharomyces cerevisia and probiotic supplementation. In contrast, Sakine et al. (2014) reported that yeast supplementation had no significant effect on the mean values of egg shell thickness of laying hens.

\subsection{Yolk quality.}

Significantly improved yolk quality (weight, color and yolk index) was observed with the addition of saccharomyces cerevisia or Aspergillus awamori, Table (3). The corresponding values of yolk weight at $\mathbf{4 0}$ wks were 
A. M. H. Abou-Ashour, et al.,

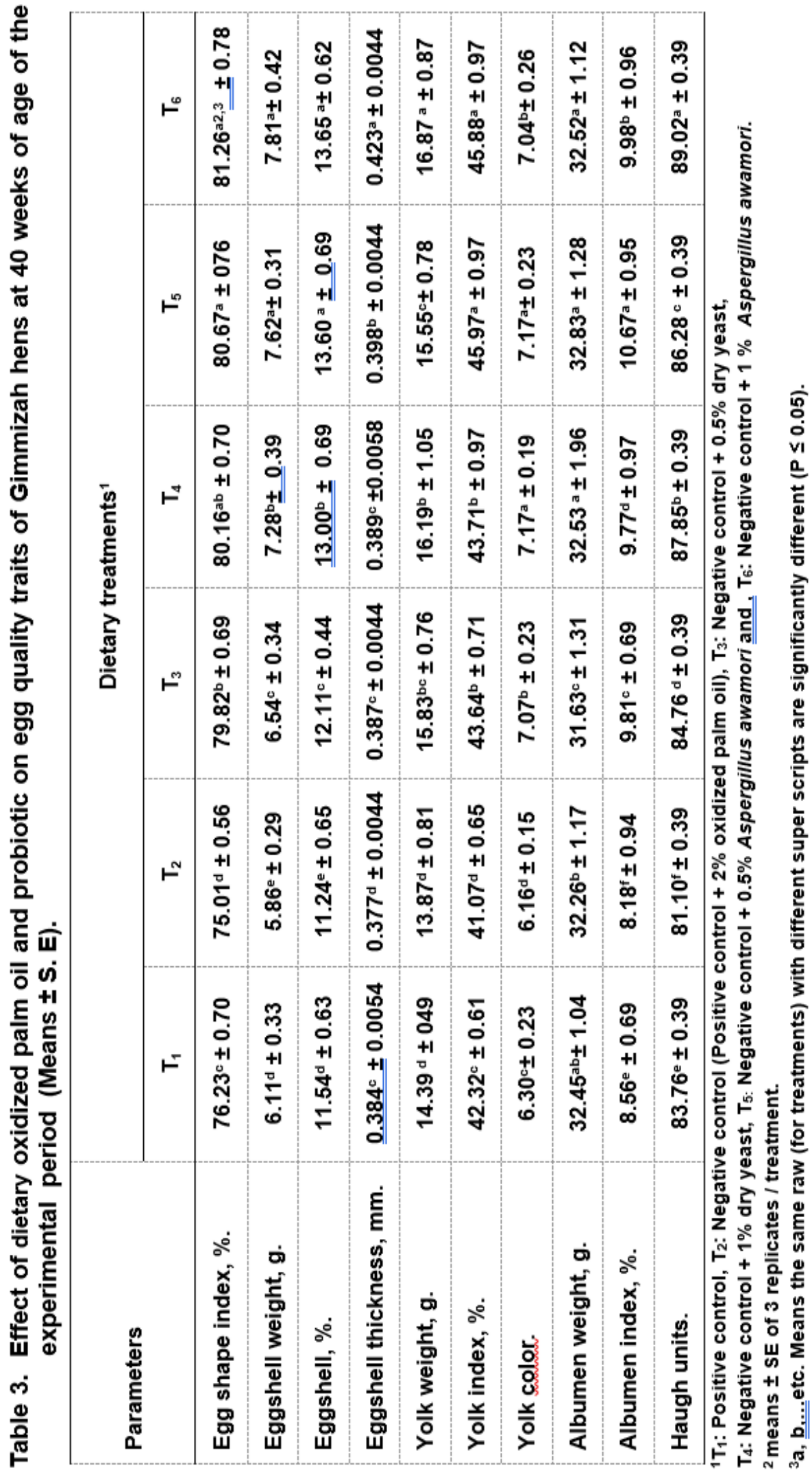


(2007) did not find any effect on egg yolk of laying 15.83, 16.19, 15.55 and $16.87 \mathrm{~g}$ for $\mathrm{T}_{3}, \mathrm{~T}_{4}, \mathrm{~T}_{5}$ and $\mathrm{T}_{6}$ and yolk color values were $7.07,7.17,7.17$ and 7.04 and 43.64, 43.71, 45.97 and $45.88 \%$ for yolk index for $T_{3}, T_{4}, T_{5}$ and $T_{6}$, groups,

hens fed yeast and probiotic supplemented diet.

\subsection{Albumen quality.}

The finding on albumen quality (albumen weight, index and Haugh units) are given in Table (3). The highest value of albumen weight noted by supplementation $1 \%$ Aspergillus $\left(T_{6}\right)$ in diet was $32.52 \mathrm{~g}$ compared with the positive and thenegative control (32.45 and $32.26 \mathrm{~g}$ ) at $40 \mathrm{wk}$. A significant difference was noted in albumen index values between dietary treatments; being $8.56,8.18,9.81,9.77,10.67$ and $9.98 \%$ for positive, negative control, $0.5,1 \%$ dry yeast, 0.5 and $1 \%$ Aspergillus, respectively.

Haugh units (albumen quality factor) were significantly improved with dietary probiotic supplementation. The highest value was obtained for groups fed $1 \%$ of Saccharomyces cerevisia and Aspergillus awamori, $\mathrm{T}_{4}$ and $\mathrm{T}_{6}$ being; 87.85 and 89.02, respectively in comparison with positive, negative control and other treatments.

Haugh units, is an indicator of the most widely accepted measure of internal egg quality, tended to decrease according to the elapsed time of storage (Williams, 1992). Surai, 2000 suggested that certain antioxidants such as yeast, and Asperiglus being beneficial to albumen quality by it's antioxidant property. It is also suggested that dietary antioxidant nutrients and natural antioxidants are effective in improving the quality of eggs during extended storage. Özek (2012) also found that dietary mannan oligosaccharide (MOS) respectively. Ayanwale et al. (2006) recorded that yolk weight was higher in laying hens fed diets having $7.5 \mathrm{~g} / \mathrm{kg}$ dried yeast. However, Maziar et al.

supplementation significantly modified albumen height and Haugh units.

Different results were recorded by Chumpawadee et al. (2009) who reported that addition of yeast in commercial layer hens diet had not any positive effect on Haugh units. Elnagar, (2013) reported that diets supplemented with live yeast did not influence egg albumin weight and percentages.

\section{4- Plasma blood parameters and blood lipid profile.}

The effect of dietary treatments on plasma constituents and plasma blood lipid profile are summarized in Table (4). Data concerning the effect of oxidized palm oil and probiotic on blood plasma constituents at the end of the experimental period 40 weeks of age revealed that dry yeast and Aspergillus, $\left(0.5 \%\right.$ and $1 \% ; T_{3}, T_{4}, T_{5}$ and $T_{6}$, respectively) are significantly $(P \leq 0.05)$ improved total protein, albumin and globulin compared to the positive and negative controls group.

Globulin is a source of antibody production, so its level in the serum is a good indicator of immune responses and consequently better disease resistance (Griminger and Scances 1986). The results of blood protein and globulin did not agree with those obtained by Wakwak et al. (2003) did not find any effect on blood protein or albumin due to adding yeast into growing quail diets. In this study, the concentration of plasma blood glucose was significantly $(P \leq 0.05)$ differences between all dietary treatments $(250.00,265.50,196.00$ and $252.50 \mathrm{mg} / \mathrm{dl}$ ) compared to $\mathrm{T}_{1}$, unsupplemented and $T_{2}$, basal diet with 


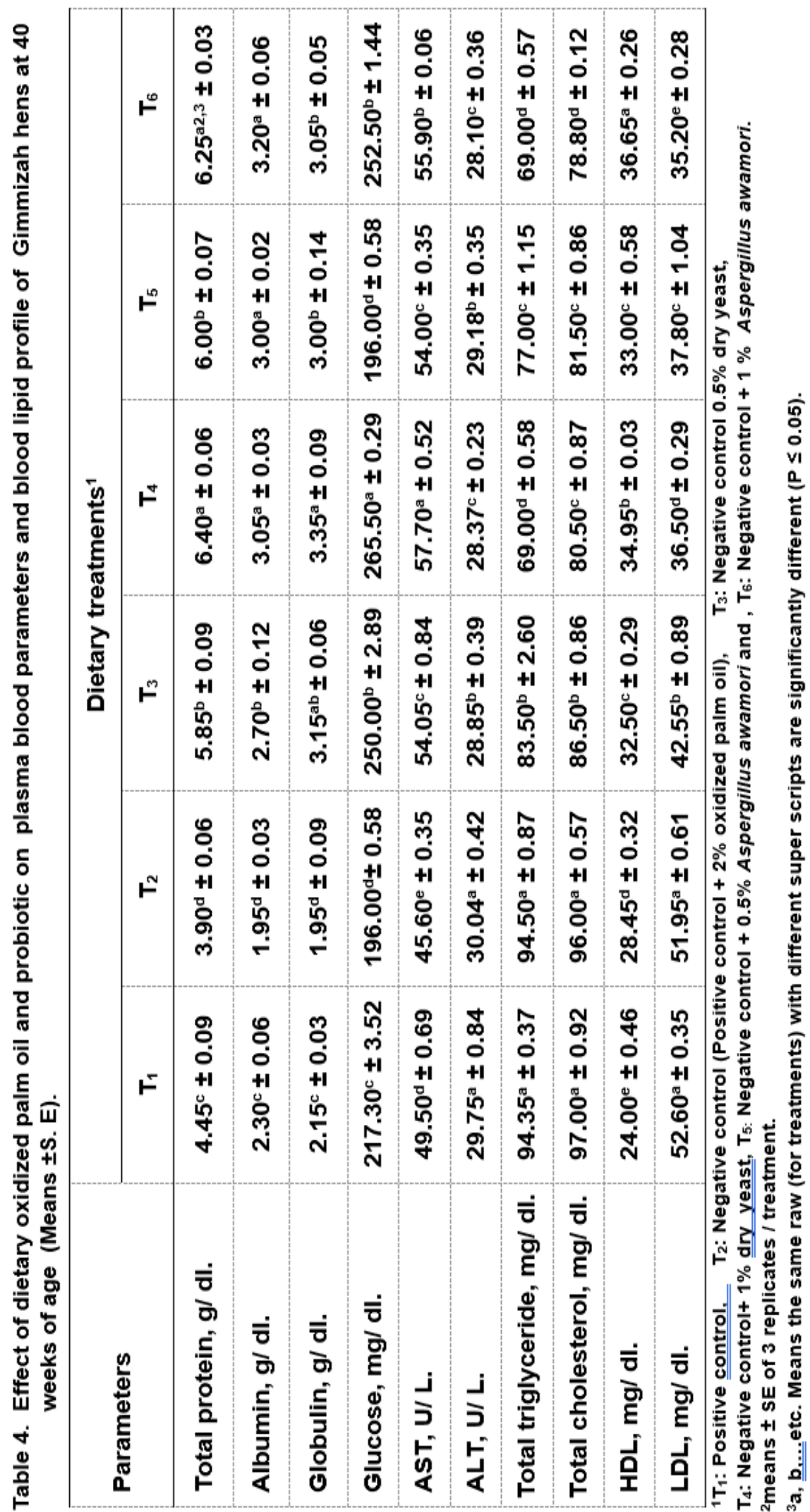


oxidized dietary palm oil $(217.30$ and $196.00 \mathrm{mg} / \mathrm{dl}$, respectively at 40 weeks of age. AST was significantly $(P \leq 0.05)$ increased, while ALT was significantly $(P$ $\leq 0.05$ ) decreased with adding probiotic (dry yeast or Aspergillus awamori) compared to positive or negative control

positive control treatment $(29.75 \mathrm{U} / \mathrm{L})$ and the negative control $(30.04 \mathrm{U} / \mathrm{L})$. On the contrary, Elnagar (2013) and Sakine et al. (2014) noted that, there were no significant differences in the serum levels of total protein, AST and ALT by the addition of yeast culture.

Laying hens fed diets contained Saccharomyces cerevisia and Aspergillus awamori had significantly ( $P$ $\leq 0.05$ ) lower serum total triglyceride being $83.50,69.00,77.00$ and $69.00 \mathrm{mg} /$ $\mathrm{dl}$, total cholesterol $86.50,80.50,81.50$ and $78.80 \mathrm{mg} / \mathrm{dl}$ and Low-density lipoprotein (LDL) 42.55, 36.50, 37.80 and $35.20 \mathrm{mg} / \mathrm{dl}$ for $\mathrm{T}_{3}, \mathrm{~T}_{4}, \mathrm{~T}_{5}$ and $\mathrm{T}_{6}$, respectively and significantly $(P \leq 0.05)$ increased high-density lipoprotein (HDL) at $\mathbf{4 0}$ weeks of age (Table 4 ) at $\mathbf{4 0}$ weeks of age when compared to the positive and negative control $(94.35$ and $94.50 \mathrm{mg} /$ dl for total triglyceride and 97.00 and $96.00 \mathrm{mg} / \mathrm{dl}$ for total cholesterol).

Hens fed the positive and negative control diet had significantly decreased $(P \leq 0.05)$ HDL $(24.00$ and $28.45 \mathrm{mg} / \mathrm{dl})$, while values of HDL were significantly improved by the addition levels of 0.5 and $1 \%$ of Saccharomyces cerevisia and Aspergillus awamori in laying hen diets being; $32.50,34.95,33.00$ and $36.65 \mathrm{mg} /$ $\mathrm{dl}$, respectively (Table 4). The decrease in blood lipid profile may be due to the beneficial role of probiotic in decreasing the microbial intracellular $\mathrm{pH}$. Thus, inhibits the action of important microbial enzymes and forces the bacterial cell to use energy to release the acid protons, leading to an intracellular accumulation of acid anions (Young and Foegeding, groups. Gimmizah laying hens fed diet supplemented with $0.5 \%\left(T_{3}\right), 1 \%\left(T_{4}\right)$ dry yeast and $0.5 \%$ and $1 \%\left(T_{5}\right.$ and $\left.T_{6}\right)$ Aspergillus awamori had the lowest value of $\operatorname{ALT}(28.85,28.37,29.18$ and 28.10 U/L), respectively in comparison with the

1993).

Also, probiotic may contribute in the regulation of serum cholesterol concentrations conducted by deconjugated bile acids. As cholesterol is a precursor for bile acid formation and when deconjugated bile acids excretion is enhanced by probiotics supplementation, then more precursor molecules are needed for the recovery of bile acid formation (Ezema and Eze, 2015). Consequently, it may be expected that level of serum cholesterol decreases (Park et al., 2008 and Sutarpa et al., 2011). Moreover, Klaver and Van Der Meer (1993) also suggested that coprecipitation with bile acids may be of importance in decreasing serum cholesterol concentrations. Moreover the observed hyperthroidism associated with dietary probiotic could also explain the observed reduction in serum lipid profile.

In accordance with the present result, Kim et al. (2003) also found that Aspergillus oryzae at $0.1 \%$ in the diet significantly lowered serum cholesterol in broiler chickens. Mahdavi et al. (2005) realized that using the different levels of probiotic caused significant decrease in plasma cholesterol, plasma triglyceride. Aspergillus on plasma cholesterol and triacylglyceride, (TAG) could be related to an inhibitor of 3-hydroxy-3-methyl-glutarylcoenzyme A reductase (HMG - CoA reductase) Hajjaj et al., (2005). Indeed, mRNA of muscle HMG - CoA reeducates was decreased by Aspergillus awamori feeding. It is well known that the HMG - CoA 
reductase inhibitor (Statin) was extracted from a fungus (Endo, 1985) and Statin is widely used to decrease LDL - cholesterol and TAG and to increase HDL - cholesterol in the plasma. Muscle HMG - CoA reductase may also be responsible for the decrease in fat deposition.

These results indicate that Aspergillus awamori produces antioxidative substances. In fact, Kaminishi et al. (1999) have found that several strains of Aspergillus produce anti oxidative substances. In addition, Salah et al. (2017) and Tapingkae et al. (2018) reported that, cholesterol and triglyceride in serum and yolk were significantly $(P \leq$ 0.05) lowered in the laying hens fed diet administrated with yeast and probiotic compared to the control (untreated hens). The reduction in cholesterol level in serum could be explained by the reduced absorption and/or synthesis of cholesterol in the gastrointestinal tract. Ezema and Eze, (2015) and Bidura et al. (2016) stated that the use of probiotic on diet may significantly lowered levels of cholesterol in serum of native local chickens. Moreover, El-Kaiaty et al. (2019) found that administrated of yeast in laying hen diets significantly $(P \leq 0.05)$ lowered serum total lipids, cholesterol and triglycerides levels compared to unsupplemented control group. However, the lowest concentrations of total lipids, cholesterol and triglycerides were recorded for hens fed diet supplemented with $0.6 \%$ yeast.

In contrast, there were no significant differences in the serum levels of total triglyceride and cholesterol by the addition of yeast culture (Yalcin et al., 2010 and Sacakli et al., 2013).

\section{Economic efficiency.}

The economic efficiency of the experimental treatments are shown in Table (5) and showed that the highest economic efficiency $47.32 \%$ and relative economic efficiency (102.56) were obtained with the diet containing $1 \%$ Aspergillus awamori $\left(\mathrm{T}_{6}\right)$. This may be due to the better feed conversion ratio obtained in birds received the experimental diet compared to other diets. While the lowest economic efficiency (36.45\%) and relative economic efficiency (79.00) was found in the negative control diet $\left(\mathrm{T}_{2}\right)$.

Table 5. Effect of dietary oxidized palm oil and probiotic on economic efficiency of Gimmizah hens during the experiment period.

\begin{tabular}{|c|c|c|c|c|c|c|}
\hline \multirow{2}{*}{ Items } & \multicolumn{6}{|c|}{ Dietary treatments ${ }^{1}$} \\
\hline & $\mathrm{T}_{1}$ & $\mathrm{~T}_{2}$ & $\mathbf{T}_{3}$ & $\mathrm{~T}_{4}$ & $\mathrm{~T}_{5}$ & $\mathrm{~T}_{6}$ \\
\hline Price of $\mathrm{Kg}$ feed, (L. E.). & 4.52 & 4.60 & 4.65 & 4.71 & 4.67 & 4.75 \\
\hline Total feed intake / hen, $(\mathrm{Kg})$. & 9.34 & 8.85 & 9.55 & 9.68 & 9.67 & 9.80 \\
\hline Total feed cost hen, (L.E.) & 42.22 & 40.71 & 44.41 & 45.49 & 45.16 & 46.55 \\
\hline Total number of eggs/hen, egg). & 47.46 & 42.73 & 50.19 & 51.22 & 51.00 & 52.75 \\
\hline Total price of eggs / hen, (L.E.) ${ }^{3}$. & 61.70 & 55.55 & 65.25 & 66.59 & 66.30 & 68.58 \\
\hline Net revenue / hen, (L.E.) ${ }^{4}$. & 19.48 & 14.84 & 20.84 & 21.00 & 21.14 & 22.03 \\
\hline Economic efficiency, $(\%)^{5}$. & 46.14 & 36.45 & 46.93 & 46.06 & 46.81 & 47.32 \\
\hline
\end{tabular}




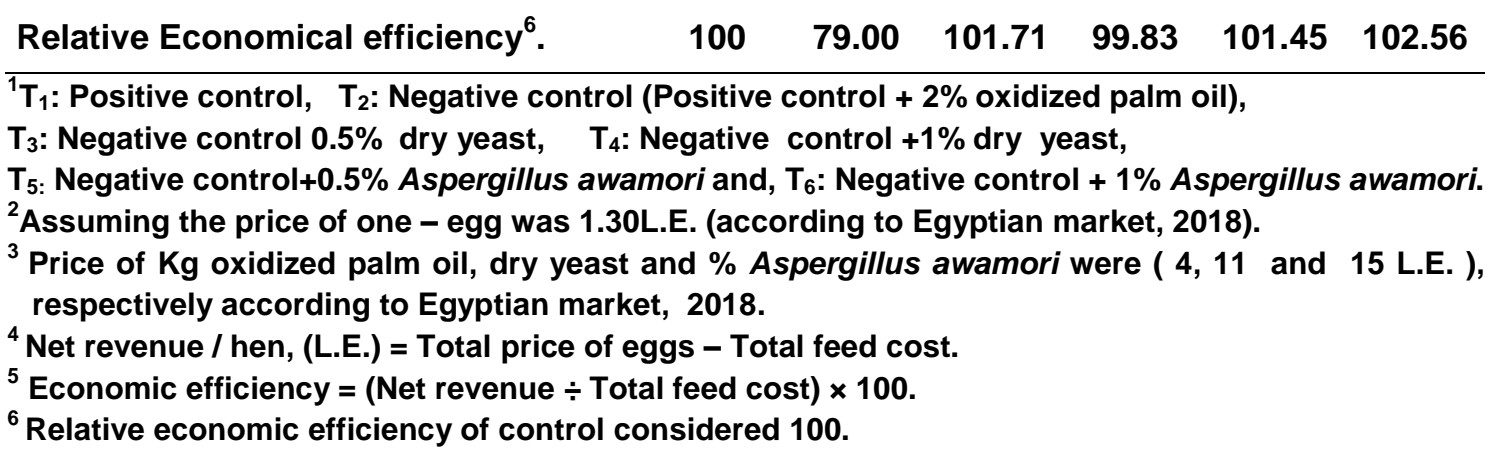

\section{REFERENCES}

Abudabos, A. M., A. H. Alyemni, Y. M. Dafalla and R. U. Khan (2017). Effect of organic acid blend and Bacillus subtilis alone or in combination on growth traits, blood biochemical and antioxidant status in broilers exposed to Salmonella typhimurium challenge during the starter phase. J. Appl. Anim. Res., 45, 538 - 542.

Ahiwe, E. U., A. A. Omede, M. B. Abdallh and P. A. lji (2018). Managing dietary energy intake by broiler chickens to reduce production costs and improve product quality. Anim. Husb. and Nutr., 22: 115 -145.

Allain, C., L. Poon, C. G. Chan, W. Richmond and C. F. Paul (1974). Enzymatic determination of total serum cholesterol. Clinical chemistry. Vol., 20/4, 470-475.

AOAC, (2005). Association of official analytical chemists $17 \mathrm{ed}$ assoc. off. Anal Chm., Arlington, VA.

Asli, M. M., S. A. Hosseini, H. Lotfollahian and F. Shariatmadari (2007). Effect of probiotics, yeast, vitamin $E$ and vitamin $C$ supplements on performance and immune response of laying hen during high environmental temperature. Inter. J. Poult. Sci., 6 (12): $895-900$.

Ayanwale, B. A., M. Kpe and V. A. Ayanwale (2006). The effect of supplementing Saccharomyces cerevisiae in the diets on egg laying and egg quality characteristics of pullets. Inter. J. Poult. Sci., 5(8): 759 763.

Bansalyz, P. N., R. C. Stewartz, V. Entezariy, B. D. Snydery and M. W. Grinstaff (2011). Contrast agent electrostatic attraction rather than repulsion to glycosaminoglycans affords a greater contrast uptake ratio and improved quantitative CT imaging in cartilage. Osteoarthritis and Cartilage, 19: 970 - 976.

Bidura, I. G. N. G., I. B. Sudana, I. P. Suyadnya, I. G. Mahardika, I. B. Gaga Partama and I. G. A. I. Aryani (2012). The implementation of Saccharomyces spp. $\mathrm{n}-2$ isolate culture (isolation from traditional yeast culture) for improving feed quality and performance of male Bali duckling. Agric. Sci., Res. J., 2 (9): 486 $-49$.

Bogin, E. and P. Keller (1987). Application of clinical biochemistry of medically relevant animal models and standardization and quality control in animal biochemistry. J. clin. Chem. Clin. Biochem., 25: 873 - 878.

Bradley, G. L. and T. F. Savage (1995). The effect of autoclaving a yeast culture of Saccharomyces cerevisiae on turkey poult performance and the retention of gross energy and selected minerals. Anim. Feed Sci. and Tech., 55: 1 - 7.

Brant, A. W. and A. Ashrader (1952). Shell quality and bacterial infection of shell eggs. Poul. Sci., 57: 638. 
Choe, E. and D. B. Min (2007). Chemistry of deep-fat frying oils. J. Food Sci., 72: 77 - 86.

Chumpawadee, S., A. Chantiratikul and S. Sataweesuk (2009). Effect of dietary inclusion of cassava yeast as probiotic sSource on egg production and egg quality of laying hens. Inter. J. Poult. Sci., 8 (2): 195 - 199.

Chung, M. K., J. H. Choi, Y. K. Chung and K. M. Chee (2005). Effects of dietary vitamins $C$ and $E$ on egg shell quality of broiler breeder hens exposed to heat stress. Asian-Aust. J. Anim. Sci., 18 (4): 545-551.

Daneshyar, M., H. Kermanshahi and A. Golian (2009). Changes of biochemical parameters and enzyme activities in broiler chickens with cold-induced ascites. Poult. Sci., 88 (1): 106 - 10.

Doumas, B., W. Watson and H. Biggs (1977). Albumin standard and measurements of serum albumin with bromocresol green. Clin. Chem. Acta., 31: 87 - 88.

Duncan, D. B. (1955). Multiple range and multiple F test. Biometrics, 11:1 - 42.

Ehr, I. J., B. J. Kerr and M. E. A. Persia (2015). Effects of peroxidized corn oil on performance and abdominal fat pad weight in broiler chicks. Poult. Sci., 94:1629 - 1634.

Eisen, E. J., B. B. Bohren and M. Mckea (1962). The Haugh unit as a measure of egg albumen quality. Poult. Sci., 41: 1441 - 1461.

El-Kaiaty, A. M., A. M. Badran, A. A. Bayoumi, Abeir A. Eshera and O. A. El-Sayed (2019). Effect of dietiary yeast supplementation on productive performance, eggshell quality and lipid profile of laying hens. Egypt. Poult. Sci., 39 (2): 567 - 578.

Elnagar, H. M. S. (2013). Effect of dried yeast (Saccharomyces cerevisiae) supplementation as feed additive to laying hen diet on egg production, egg quality, carcass traits and blood constituents. Egypt, J. Anim. Prod., 50 (2): 111 - 115.

Endo A. (1985). Compactin (ML-236B) and related compounds as potential cholesterol-lowering agents that inhibit HMG-CoA reductase. J. Med. Chem., 28: 401 - 405.

Ezema, C. and D. C. Eze (2015). Probiotics effect of yeast (Saccharomyces cerevisiae) on henday egg performance, serum and egg cholesterol levels in laying chicken. Pakistan, J. Nutr., 14 (1): 44 - 46.

FAO/ WHO (2001). Report of a joint FAO/WHO expert consultation on evaluation of health and nutritional properties of probiotics in food including powder milk with live lactic acid bacteria. CÓrdoba, Argentina (October 1 - 4).

Funk, E. M. (1948). The relationship of the yolk index determined in natural position to the yolk as determined after separating the yolk from the albumin. Poult. Sci., 27: 367.

Griminder. P.: and C. G. Scanes (1986). Protein metabolism. In: Avian Phvsioloav. 4th ed. (Sturkie. P. D.. Ed.). Snrinaer Verlad. New York. Berlin. Heidelbera. Tokvo. nn. 326 345.

Gül, M., M. A. Yörük, Y. S. Sağlam and T. Aksu (2013). Yumurta tavuğu rasyonlarına maya (Saccharomyces cerevisiae) ve Enterococcus faecium katkılarının performans, yumurta kalite kriterleri ve barsak mikroflorası üzerine etkileri. Atatürk Üniversitesi Veteriner Bilimleri Dergisi, 8 (2): 137 144.

Hajjaj, H., P. Duboc and L. B. Fay (2005). Aspergillus oryzae produces compounds inhibiting cholesterol biosynthesis downstream of dihydrolanosterol. FEMS Microbiol Lett., 242: 155 - 159. 
Haugh, R. R. (1937). The Haugh unit for measuring egg quality. US Egg Poult. Mag., 43: 522 - 555.

Heady, E. O. and H. R. Jensen (1954). Farm management economics. Pentice-Hall Inc. Englewood ctiffs $\mathbf{N}$. J., USA.

Henry, D. G., R. Rent and J. Siegel (1974). Interactions of c-reactive protein with the complement system. J. Experimental Medicine. Vol., 140: 631647.

Hong, K. J., C. H. Lee and S. W. Kim (2004). Aspergillus oryzae GB-107 fermentation improves nutritional quality of food soybeans and feed soybean meal. J. Med. Food, 7: 430 435.

Hussein, E. and S. Selim (2018). Efficacy of yeast and multi-strain probiotic alone or in combination on growth performance, carcass traits, blood biochemical constituents, and meat quality of broiler chickens. Livestock Sci., 216: 153-159.

Iqbal, M., D. Cawthon, K. Beers and W. G. Bottje (2002). Antioxidant enzyme activities and mitochondrial fatty acids in pulmonary hypertension syndrome (PHS) in broilers. Poult. Sci., 81, 252 - 260.

Kalavathy, R., N. Abdullah, S. Jalaludin, M. Wong and Y. W. Ho (2009). Effects of Lactobacillus cultures on performance of laying hens, and total cholesterol, lipid and fatty acid composition of egg yolk. J. Sci., Food Agric., 89: 482 - 486.

Kaminishi, Y., J. Egusa and M. Kunimoto (1999). Antioxidant pro-duction from several xerophilous fungi used in "Katsuo-bushi" molding. J. Natl. Fish Univ., 47: 113 - 120.

Karaoglu, M. and H. Durdag (2005). The influence of dietary probiotic Saccharomyces cerevisiae supplementation and different slaughter age on the performance, slaughter and carcass properties of broilers. Int. Poult. Sci., 4: 309 - 316.

Kim, S. H., S. Y. Park, S. J. Lee and K. S. Ryu (2002). Effects of single or mixed feeding of lactobacillus and yeast on performance, nutrient digestibility intestinal microflora, and fecal $\mathrm{NH} 3$ gas emission in laying hens. Korean J. Poult. Sci., 29 (93): 225 - 231.

Kim, S. H., S. Y. Park and D. J. Yu (2003). Effects of feeding Aspergillus oryzae ferments on performance, intestinal microflora, blood serum components and environmental factors in broiler. Korean J. Poult. Sci., 30: 151 - 159.

Klaver, F. A. M. and R. Van-Der-Meer (1993). The assumed assimilation of cholesterol by lactobacilli and Bifidobacterium bifidum is due to their bile salt-deconjugating activity. Appl. Environ. Microbiol., 59: 1120 - 1124.

Kotaiah, T. and S. C. Mohapatra (1974). Measurement of albumen quality. India. Poult. Ganzette. 59:121.

Liu, P., B. J. Kerr, T. E. Weber, C. Chen, L. J. Johnston and G. C. Shurson (2014). Influence of thermally oxidized vegetable oils and animal fats on intestinal barrier function and immune variables in young pigs. J. Anim. Sci., 92: 2971 - 2979.

Mahdavi, A. H., H. R. Rahman and J. Pourrezaj (2005). Effect of probiotic supplements on egg quality and laying hen's performance. Inter. J. Poult. Sci., 4 (7): 488 - 492.

Maziar, M. A., S. A. Hosseini, H. Lotfollahian and F. Shariatmadar (2007). Effect of probiotics, yeast, vitamin $E$ and vitamin $C$ supplements on performance and immune response of laying hen during high environmental temperature. Inter. J. Poult. Sci., 6 (12): 895 - 900.

Mersmann, H. J. (1998). Lipoprotein and hormone-sensitive lipases in porcine 
adipose tissue. J. Anim. Sci., 76:1396 $-1404$.

Mohan, B., R. Kadirvel and A. Natarajan (1996). Effect of probiotic supplementation on growth, nitrogen utilization and serum cholesterol in broilers. Br. Poult. Sci., 37, 395 - 401.

Mujahid, A., Y. Akiba and M. Toyomizu (2009). Progressive changes in the physiological responses of heatstressed broiler chickens. J. poult., Sci., Vol.,46:163 - 167.

National Research Council (NRC), (1994). Nutrient requirements of poultry. 9 Rev. ed Ed., National Academy press, Washington, DC.

Önol, A. G., M. Sari, F. K. Oguz, B. Gulcan and G. Erbas (2003). Sürekli sýcak stresinde bulunan yumurtlama dönemindeki bildircinlarin rasyonlarina probiotik katkisinin bazi verim ve kan parametreleri üzerine etkisi. Türk Veterinerlik ve Hayvancilik Dergisi, 27: 1397 - 1402.

Özsoy, B. and S. yalcin (2011). The effects of dietary supplementation of yeast culture on performance, blood parameters and immune system in broiler turkeys. Ankara Univ. Vet. Fak. Derg., 58, 117 - 122.

Panda, A. K., S. S. R. Rao, M. V. L. N. Raju and S. S. Sharma (2008). Effect of probiotic (Lactobacillus sporogenes) feeding on egg production and quality, yolk cholesterol and humoral immune response of White Leghorn layer breeders. J. Sci. Food Agric., 88: $43-47$.

Park, D. Y., H. Namkung and I. K. Paik (2001). Effect of supplementary yeast culture on the performance of laying hens. J. Anim. Sci. Tech. 43 (5): 639 646.

Park, Y. H., J. G. Kim, Y. W. Shin, H. S. Kim, Y. J. Kim, T. Chun, S. H. Kim and K. Y. Whang (2008). Effects of Lactobacillus acidophilus 43121 and a mixture of Lactobacillus casei and
Bifidobacterium longum on the serum cholesterol level and fecal sterol excretion in hypercholesterolemiainduced pigs. Biosci. Biotechnol. Biochem., 72: 595 - 600.

Puspani, E., I. G. N. G. Bidura, D.P. M. A. Candrawati and I. G. A. Aryani (2014). Pollard in diets supplemented with yeast on broiler performance and ammonia- $\mathbf{N}$ concentration of excreta. J. Biolog. Chem. Res., 31 (2): 1048 1055.

Raka, P. S., O. Sjofjan and L. Ekaradiati (2014). Effect of Liquid probiotics mixed culture supplements through drinking water on laying hens performance and yolk cholesterol. J. World's Poult. Res., 4 (1): 05 - 09.

Rauch, W., (1961). Ueber die Beeinflussung der Dotterfarbe durch carotinoidhal-tiges Legehennenfutter. 1. Mitteilung: Arch.-Gefliigelk. 23: 319331. 2. Mitteilung: Arch.-Gefliigelk. 24: 417-431. 3. Mitteilung: Arch.Gefliigelk 25:494-502.

Reitman, S. and S. Frankel (1957). A colorimetric method for the determination of serum glutamic oxalacetic and glutamic pyruvic transaminases. Americ. J. of clin. path.

Romanoff, A. L. and A. J. Romanoff (1949). The avian egg. John Wiley and sons, Inc., New York.

Romashko, A. (1999). The protein feed mixture for egg laying poultry. Vesti, Akademic, Agramykh, Navuk., 4: 64 68.

Sacakli, P., A. Ergun, B. H. Koksal, B. Ozsoy and Z. Cantekin (2013). Effects of inactivated brewer's yeast (Saccharomyces cereviciae) on egg production, serum antibody titres and cholesterol levels in laying hens. Vet. Zoo. Techn., 61: 53 - 60.

Sakine, Y., Y. Suzan, Ş. Aydın, M. D. Hayrettin, Ç. Hıdır and G. Ali (2014). Effects of dietary inactive yeast and 
live yeast on performance, egg quality traits, some blood parameters and antibody production to SRBC of laying hens. Kafkas Univ. Vet. Fak. Derg., 21 (3): $345-350$.

Saleh, A., B. Gálik, H. Arpášová, M. Capcarová, A. Kalafová, M. Šimko, M. Juráček, M. Rolinec, D. Bíro and A. M. Abudabos (2017). Synergistic effect of feeding Aspergillus awamori and lactic acid bacteria on performance, egg traits, egg yolk cholesterol and fatty acid profile in laying hens. Ital. J. Anim. Sci., 16 (1): 132 - 139.

Shashidhara, R. G. and G. Devegowda (2003). Effect of dietary mannan oligosaccharide on broiler breeder production traits and immunity. Poult. Sci., 82: 1319 - 1325.

Shen, T., J. Y. Wang and B. D. Zhao (1991). Biochemistry, pp. $151-167$. Beijing: Higher Education Press.

Skufca, P., C. Brandsch, F. Hirche and K. Eder (2003). Effects of a dietary oxidized fat on thyroid morphology and mRNA concentrations of thyroidal iodide transporter and thyroid peroxidase in rats. Ann. Nutr. Metab., 47: 207 - 213.

Smyk, B. (2015). Singlet oxygen autoxidation of vegetable oils: evidences for lack of synergy between beta-carotene and tocopherols. Food Chem., 182: 209 - 216.

Sobczak, A. and K. Kozłowski (2015). The effect of a probiotic preparation containing Bacillus subtilis ATCC PTA - 6737 on egg production and physiological parameters of laying hens. Anim. Sci., 15:711 - 723.

Soliman, A. Z. M. and M. A. Z. Abdo (2005). Evaluation of fresh garlic as natural feed additive in layer dyets varying in energy content. Egypt. Poult. Sci., 25 (1): 317 - 331.

Spring, P., C. Wenk, K. A. Dawson and K. E. Newman (2000). The effects of dietary mannan oligosaccharides on cecal parameters and the concentrations of enteric bacteria in the ceca of Salmonella-challenged broiler chicks. Poult. Sci., 79: 205 211.

SPSS, (2011). SPSS 11.0 for Windows. SPSS Inc., Chicago. Standardization ministration of china. 2005. National feed Industry Standards for Enzyme Assays in china.

Surai, P.F. (2000). Effect of selenium and vitamin $E$ content of the maternal diet on the antioxidant system of the yolk and the developing chick. Brit. Poult. Sci., 41, 235 - 243.

Sutarpa, I. N. S., S. A. Lindawati, Y. Ramona, I. N. S. Miwada, I. N. T. Ariana and M. Hartawan (2011). The effect of lactic acid bacteria administration on the performances, total bacteria in the digestive tract, and the blood and meat cholesterol content of kampong chickens. The $3^{\text {rd }}$ Inter. Confer. Bioscience and Biotechnology. Maintaining World Prosperity through Biosciences, Biotechnology and Revegetation. 2- 22 September. Udayana University, Denpasar Bali, Indonesia. Udayana University Press. pp. 110 - 112.

Tan, L., D. Rong, Y. Yang and B. Zhang (2018). Effect of oxidized soybean oils on oxidative status and intestinal barrier function in broiler chickens. Braz. J. Poult. Sci., vol. 20 no. 2 Campinas Apr./ June.

Tangendjaja, B. and I. Yoon (2002). Effect of yeast culture on egg production and mortality in layer chickens. Page 89 in Poult. Sci., Association 91st Annual Meeting Abstracts. August 11 -14. Newark, DE. Abstract No: 380.

Trinder, P. (1969). Determination of blood glucose using an oxidase-peroxidase system with a non-carcinogenic chromogen. Published as 10.1136/ jcp. 22.2.158 on 1 March. 
Umiarti, A.T. and I. G. N. G. Bidura (2014). Influence of Saccharomyces spp culture level in the ration on the performances and the levels of ammonia gas in chicken excreta. The Magazine Scientific Ranch (Indonesia), 17 (3): 79 - 84.

Wakwak, M. M., Nagla S. F. El-Afifi, K. Soliman and M. Attia (2003). Effect of adding active dried yeast into Japanese quail diets on performance, some immunity and microbiological aspects. J. Agric. Sci., Mansoura Univ., 28 (4): 2601 - 2612.

Wang, L. G., E. C. Li, J. G. Qin, Z. Y. Du and N. Yu (2015). Effect of oxidized fish oil and a-tocopherol on growth, ant oxidation status, serum immune enzyme activity and resistance to Aeromonas hydrophila challenge of Chinese mitten crab Eriocheir sinensis. Aquaculture Nutr., 21: 414 424.

Wibawa, A. A.P. P., A.A. A. S. Trisnadewi and I. B. G. Partama (2014). Supplementation of yeast in the diet containing tofu on egg production of laying hens Lohmann Brown. The Magazine Scientific Ranch. 17 (3): 85 90.

Williams, K. C. (1992). Some factor affecting albumen quality with particular reference to Haugh unit score. World's Poult. Sci. J., 48 : 5 16.

Yalcin, S., K. Çakın, Ö. Eltan and L. Dağaşan. (2010). Effects of dietary yeast autolysate (Saccharomyces cerevisiae) on performance, egg traits, egg cholesterol content, egg yolk fatty acid composition and humoral immune response of laying hens. J. Sci., Food Agric., 90: 1695 - 1701.

Yalcin, S., K. Uzunoglu, H. M. Duyum and O. Eltan (2012). Effects of dietary yeast autolysate (Saccharomyces cerevisiae) and black cumin seed (Nigella sativa $L$.) on performance, egg traits, some blood characteristics and antibody production of laying hens. Livestock Sci., 145, 13 - 20.

Yalcin, S., I. Onbaşılar, H. Eser and A. Şahin (2014). Effects of dietary yeast cell wall on performance, egg quality and humoral immune response in laying hens. Ankara Üniv. Vet. Fak Derg., 61: 289 - 294.

Yong, K.M. and M. Foegeding (1993). Acetric, lactic and citric acids and $\mathrm{pH}$ inhibition of listeria monocytogenes scotta and the effect on intracellular pH. J. Apple. Bacteriol., 75: 515 - 520.

Yörük. M. A., M. Gul, A. Hayirli and M. Macit (2004). The effects of supplementation of hamate and probiotic on egg production and quality parameters during the late laying period in hens. Poult. Sci., (83) 84 - 88.

Yue. H. Y., J. Wang, X. L. Qi, F. Ji, M. F. Liu and S. G. Wu (2011). Effects of dietary oxidized oil on laying performance, lipid metabolism, and a lipoprotein gene expression in laying hens. Poult. Sci., 90: 1728 - 1736.

Zarei, A., A. Lavvaf and M. M. Motlagh (2018). Effects of probiotic and whey powder supplementation on growth performance, microflora population, and ileum morphology in broilers. J. Appl. Anim. Res., 46: $840-844$.

Zhang, Z.F. and I. H. Kim (2014). Effects of multistrain probiotics on growth performance, apparent ileal nutrient digestibility, blood characteristics, cecal microbial shedding, and excreta odor contents in broilers. Poult. Sci., $93,364-370$.

Zhang, Z. F., T. X. Zhou and I. H Kim (2012). Effects of b-glucan and Bacillus subtilis on growth performance, blood profiles, relative organ weight and meat quality in broilers fed maize soybean meal 
424.

تأثير إضافة الخميرة الجافة أو الأسبرجلس أمورى كمضات أكسدة طبيعية إلى العلائق

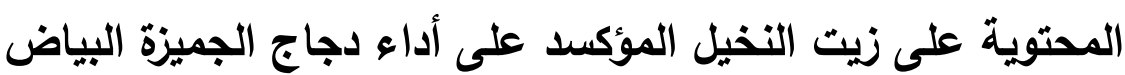

عاطف محمد حسن أبو عاشور، جمال عبد الستار زناتى، إسراء يوسف فتحى عطال اله قسم إنتاج الدواجن والأسماك - كلية الززاعة - جامعة المنوفية - مصر.

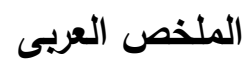

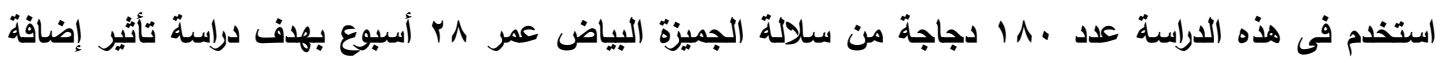

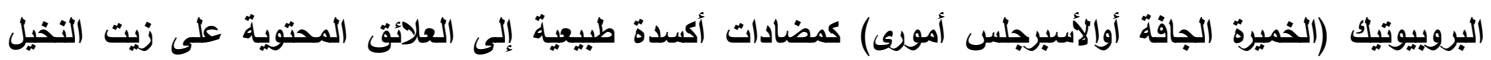

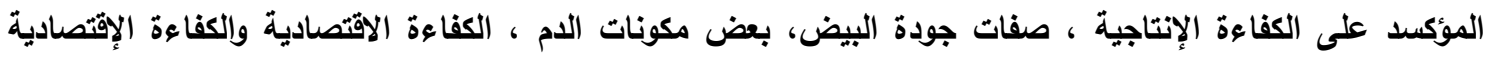

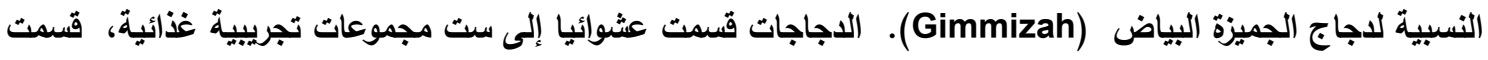

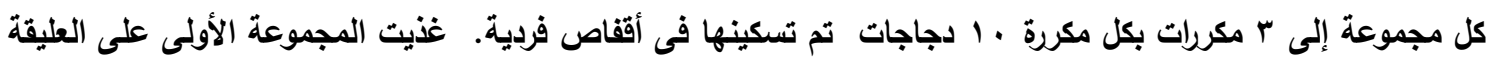

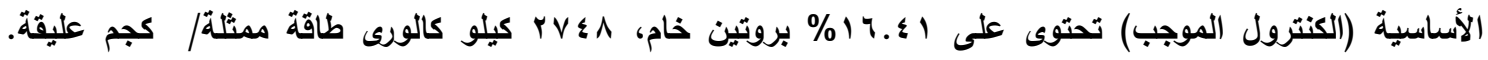

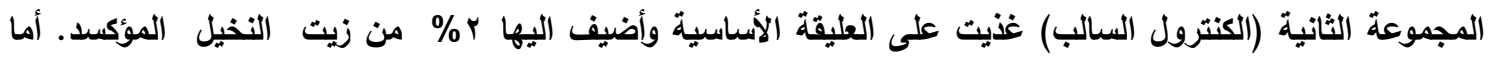

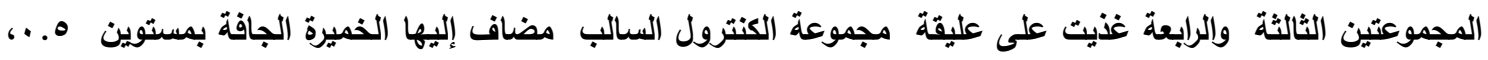

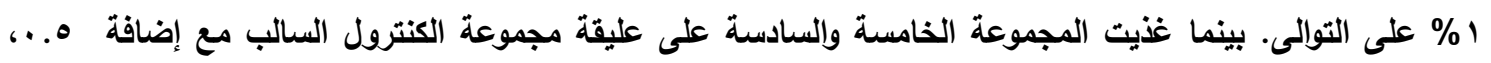

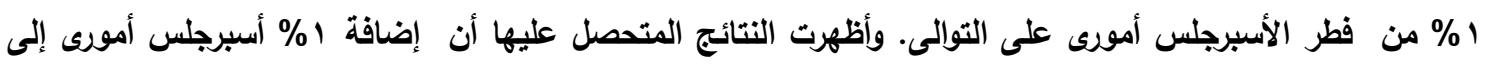

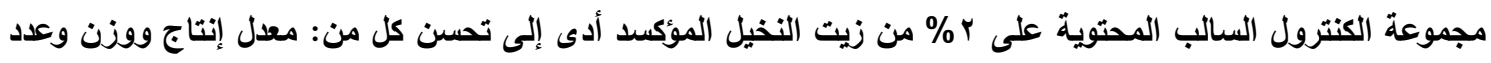

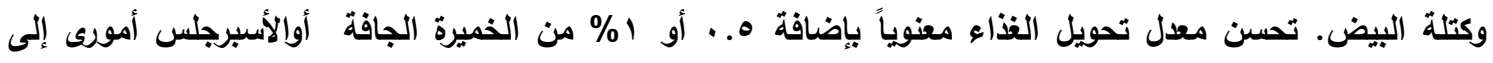

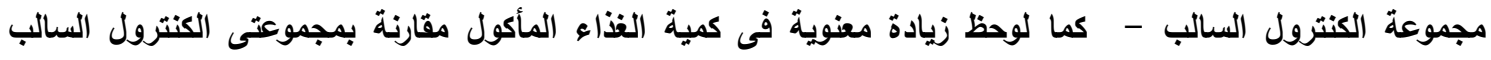

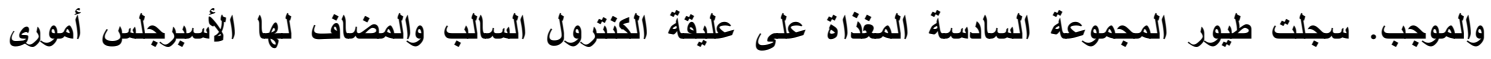

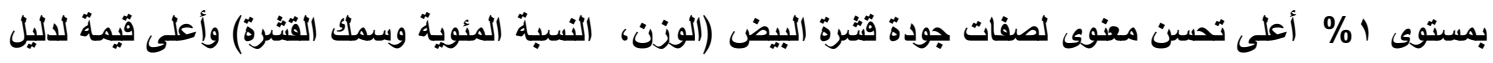

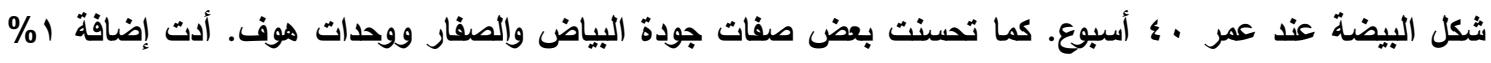

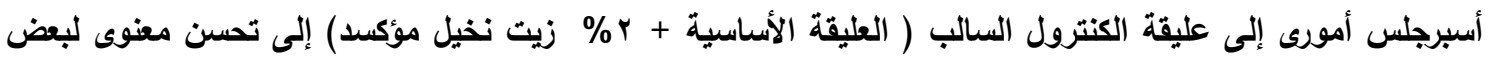

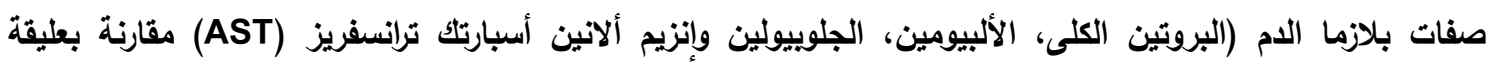




\section{A. M. H. Abou-Ashour, et al.,}

الكنترول السالب والموجب. لوحظ انخفاضاً معنوياً فى تركيز كل من الكوليسترول الكلى والدهون الثلاثية الكلية وكذلك

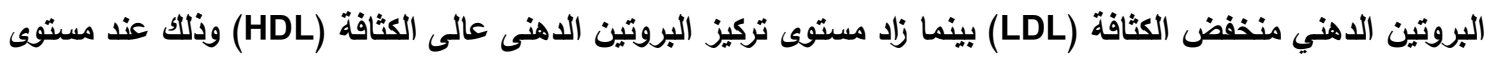

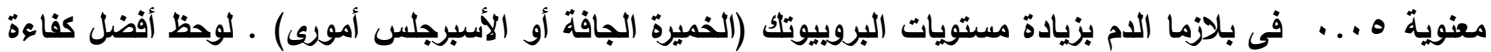
إقتصادية وكفاءة إقتصادية نسبية لعليقة المعاملة السادسة (1\% أسبرجلس أمورى) مقارنة بباقى المعاملات. بصفة

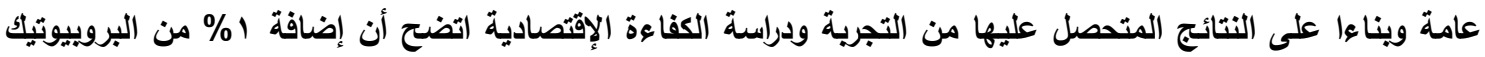

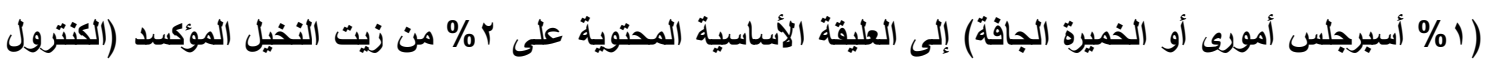

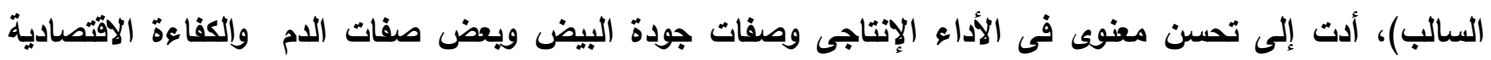
والكفاءة الاقتصادية النسبية لاجاجات الجميزة البياض تحت ظروف التجربة.

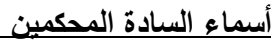

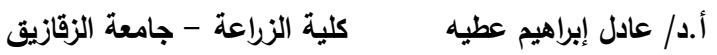
أ.د / منال كمال أبوالنجا كلية الزراعة - جامعة المنوفية 